\title{
PERBANDINGAN PENGETAHUAN REMAJA MENGENAI PENDEWASAAN USIA PERKAWINAN MELALUI METODE FASIL DAN SIMULATION GAME
}

\author{
Puspa Sari, ${ }^{1}$ Ari Indra Susanti, ${ }^{2}$ Sri Astuti, ${ }^{3}$ Merry Wijaya ${ }^{4}$ Eka Noyan Nur Annisa ${ }^{5}$ \\ ${ }_{1,2,3,4}$ Departemen Ilmu Kesehatan Masyarakat Fakultas Kedokteran Universitas Padjadjaran, Indonesia \\ ${ }^{5}$ Jurusan Kebidanan Fakultas Kedokteran Universitas Padjadjaran, Indonesia
}

Informasi Artikel:

Diterima: November 2016

Disetujui: September, 2017

*Korespondensi penulis.

ekanoyann@gmail.com

\begin{abstract}
ABSTRAK
Permasalahan masalah kesehatan reproduksi, diantaranya usia perkawinan pertama di bawah usia 20 tahun. Penelitian ini bertujuan untuk mengetahui perbandingan pengetahuan remaja mengenai Pendewasaan Usia Perkawinan (PUP) melalui metode fasil dan simulation game di salah satu SMP di wilayah Jatinangor. Penelitian ini adalah penelitian quasi eksperimental dalam bentuk pretest-posttest design yang dilakukan pada tanggal 2 Agustus 2016. Sampel dalam penelitian ini adalah siswa dan siswi kelas IX SMP Negeri 1 Jatinangor yang berusia 13-15 tahun. Pengambilan sampel dilakukan dengan teknik random sampling dengan jumlah sampel 20 responden dengan metode fasil (kelompok kontrol) dan 20 responden dengan metode simulation game (kelompok eksperimen). Metode pendidikan kesehatan dengan metode fasil dan simulation game dapat meningkatkan pengetahuan remaja mengenai. Analisis data menggunakan Uji Wilcoxon. Hasil penelitian menunjukkan bahwa tidak terdapat perbedaan pengetahuan remaja sebelum dan sesudah diberikan pendidikan kesehatan mengenai PUP dengan metode fasil maupun metode simulation game $(p>0,05)$. Tidak terdapat perbedaan yang signifikan terhadap pengetahuan remaja mengenai PUP setelah diberikan pendidikan kesehatan dengan metode fasil dan simulation game $(p>0,05)$.
\end{abstract}

Kata kunci: Fasil, Simulation Game, Pendewasaan Usia Perkawinan, Pendidikan kesehatan, Pengetahuan remaja.

\begin{abstract}
Adolescent, nowadays, are still susceptible of the reproductive health problem, especially for them who were married under the age of 20 years old. This study aimed to find out the comparison of adolescent's knowledge about marriage age maturation through fasil and simulation game. Quasi experimental with pre-test and post-test design was applied in this study. It was conducted on 02 August 2016. The samples of the study were the third graders of SMP Negeri 1 Jationangor with the range of age 13-15 years old. The samples involved in this study were randomly taken and devided into two groups, that were control and experimental groups, with 20 respondents in each. The control group was applied the fasil method, while the experimental group was applied the simulation game method. Then, at the end, the data gained were analyzed by Wilcoxon test. The result of the study showed the two methods can improve the of adolescent's knowledge about marriage age maturation. there was no significant difference of the adolescent's knowledge before and after given the campaign of educational health information about Marriage Age Maturation (PUP) through either fasil or simulation game methods $(p<0,05)$. Moreover, there was no significant comparison of the adolescent's knowledge about Marriage Age Maturation $(P U P)$ after given the campaign of educational health information about Marriage Age Maturation (PUP) through either fasil or simulation game methods ( $p>0,05)$. Based on the result, it can be concluded that there was no significant difference of the adolescent's knowledge about marriage age maturation after given the campaign of educational health information about marriage age maturation through either fasil or simulation game methods.
\end{abstract}

Key Words: Fasil, Simulation Game, Marriage Age Maturation, Educational health information, Adolescent knowledge. 


\section{PENDAHULUAN}

Masa remaja merupakan masa transisi dari anak-anak menuju dewasa yang melibatkan perubahan fisik, seksual, psikologi, dan sosial yang terjadi dalam waktu bersamaan. Remaja cenderung memiliki rasa ingin tahu yang besar, menyukai petulangan, dan tantangan tanpa didahului dengan pemikiran yang matang, sehingga masa remaja merupakan masa yang rentan karena seorang remaja sedang dalam upaya pencarian jati diri. Atas dasar tersebut, remaja sering melakukan berbagai macam aktivitas untuk mencari pengalaman baru, termasuk dalam hal kesehatan reproduksi. (Pitojo AJ LS, 2013; Kemenkes, 2012) Isu kesehatan reproduksi remaja menjadi sangat penting mengingat besarnya jumlah populasi remaja dan dampak jangka panjang yang ditimbulkan dari permasalahan tersebut. Remaja saat ini masih rentan terhadap permasalahan kesehatan reproduksi, diantaranya usia perkawinan pertama di bawah usia 20 tahun dan kehamilan pada usia muda. (RISKESDAS, 2010)

Menurut United Nations Development Economic and Social Affairs (UNESDA, 2010), Indonesia merupakan negara dengan angka pernikahan dini tertinggi ke-2 di ASEAN setelah Kamboja. (RISKESDAS, 2010) Hampir $10 \%$ anak perempuan menjadi ibu pada usia 16 tahun di negara miskin dan berkembang dengan angka tertinggi salah satunya di Asia Tenggara. (Morris, JL, Rushwan H, 2015) Berdasarkan Riset Kesehatan Dasar (RISKESDAS) pada tahun 2010, secara umum usia rata-rata perkawinan pertama pada usia 20 tahun, namun berdasarkan kelompok umur perkawinan pertama menunjukkan bahwa terdapat perkawinan pada usia muda yaitu 10-19 tahun sebesar 46,7\% di mana 4,8\% diantaranya terjadi pada usia 10-14 tahun dan $41,9 \%$ terjadi pada usia 15-19 tahun. $^{4}$ Provinsi Jawa Barat merupakan salah satu provinsi yang memiliki persentase perkawinan usia muda tertinggi di Indonesia, yaitu $7,5 \%$ terjadi pada usia 10 14 tahun dan 50,2\% pada usia 15-19 tahun. (RISKESDAS, 2010).

Pernikahan pada usia muda dapat meningkatkan risiko terjadinya keguguran, obstetric fistula, kanker leher rahim, dan berbagai masalah lainnya. (Fadlyana E, Larasaty S, 2009) Kehamilan pada perempuan dengan usia yang sangat muda merupakan masalah yang signifikan. Kehamilan di usia yang sangat muda berkorelasi dengan angka kesakitan dan kematian ibu. Remaja menghadapi risiko lebih tinggi yaitu komplikasi dan kematian akibat kehamilan daripada perempuan yang lebih tua. Anak perempuan yang berusia 1014 tahun berisiko lima kali lipat meninggal saat hamil maupun bersalin dibandingkan kelompok usia 20-24 tahun, sementara risiko ini meningkat dua kali lipat pada kelompok usia 15-19 tahun. Komplikasi yang dapat terjadi pada kehamilan usia muda diantaranya anemia, HIV (Human Immunodeficiency Virus) dan penyakit menular seksual lainnya, perdarahan pasca salin, dan gangguan mental seperti depresi yang berhubungan dengan kehamilan remaja. (Fadlyana E, Larasaty S, 2009; 
Hodgkinson S, et.al, 2010; Morris JL, Rushwan H, 2015)

Tingkat pengetahuan seseorang memengaruhi perilaku yang dilakukannya karena sebelum seseorang tahu terlebih dahulu apa arti dan manfaat suatu perilaku bagi dirinya maupun keluarganya ia akan mengadopsi perilaku tersebut. Berdasarkan penelitian yang dilakukan oleh Stang, terdapat hubungan yang bermakna antara pengetahuan seseorang yang melakukan pernikahn dini dan yang tidak melakukan pernikahan dini. Hasil penelitian tersebut menunjukkan bahwa responden yang memiliki pengetahuan yang rendah lebih banyak melakukan pernikahan dini karena pada umumnya belum mengetahu tentang batasan usia pernikahan dan dampak negatif yang timbul apabila menikah pada usia di bawah 20 tahun, serta kurangnya pengetahuan tentang kesehatan reproduksi. (Stang, 2011) Seorang perempuan yang mempunyai pengetahuan tentang reproduksi yang baik pasti akan lebih mempertimbangkan tentang hal usia pernikahannya karena mereka mengetahui apa saja akibat dari pernikahan usia dini terhadap reproduksinya. (Stang, 2011; Desiyanti IW, 2015).

Kurangnya informasi, pemahaman, dan kesadaran untuk mencapai sehat secara reproduksi menjadi permasalahan remaja yang berkaitan dengan kesehatan reproduksi. Hasil Survei Demografi Kesehatan Indonesia (SDKI) 2012 Kesehatan Reproduksi Remaja (KRR), menunjukkan pengetahuan remaja mengenai kesehatan reproduksi masih belum memadai, yaitu $35,3 \%$ remaja perempuan dan 31,2\% remaja laki-laki usia 15-19 tahun mengetahui bahwa perempuan dapat hamil dengan satu kali berhubungan seksual. (Kemenkes, 2012)

Dari uraian di atas, penulis tertarik untuk melakukan penelitian mengenai perbandingan metode fasil dengan simulation game terhadap pengetahuan remaja mengenai pendewasaan usia perkawinan.

\section{METODE PENELITIAN}

Metode penelitian ini dengan menggunakan jenis penelitian quasi experimental design dalam bentuk pretest-posttest design. Peneliti membandingkan pengetahuan remaja setelah diberikan pendidikan kesehatan dengan metode fasil (kelompok kontrol) dan metode simulation game (kelompok eksperimen). Penelitian ini dilaksanakan pada tanggal 2 Agustus 2016. Populasi pada penelitian ini adalah siswa dan siswi kelas IX SMP yang berjumlah 352. Jumlah sampel untuk kelompok kontrol (dengan metode fasil) sebanyak 20 responden dan untuk kelompok eksperimen (dengan metode simulation game) sebanyak 20 responden.

Kriteria inklusi adalah remaja perempuan dan laki-laki usia 13-15 tahun, sudah mendapatkan materi mengenai kesehatan reproduksi, dan belum menikah. Sedangkan kriteria eksklusi adalah remaja yang sakit dalam proses pengambilan data dan tidak datang dalam proses pengambilan data. Analisis data pada penelitian ini merupakan analisis bivariat dengan Uji Wilcoxon. 


\section{HASIL DAN PEMBAHASAN}

Tabel 1 Perbedaan Pengetahuan Remaja mengenai Pendewasaan Usia Perkawinan melalui Pendidikan Kesehatan dengan Metode Fasil

\begin{tabular}{cccccc}
\hline \multirow{2}{*}{ Pengetahuan } & \multicolumn{3}{c}{ Metode Fasil } & \multirow{2}{*}{ Nilai p } \\
\cline { 2 - 4 } & \multicolumn{2}{c}{ Pre-test } & \multicolumn{2}{c}{ Post-test } & \\
\cline { 2 - 5 } & $(\mathrm{n})$ & $(\%)$ & $(\mathrm{n})$ & $(\%)$ & \\
\hline Baik & 3 & 15 & 7 & 35 & 0,376 \\
Cukup & 10 & 50 & 9 & 45 & \\
Kurang & 7 & 35 & 4 & 20 & \\
\hline Total & 20 & 100 & 20 & 100 & \\
\hline
\end{tabular}

Berdasarkan tabel 1, didapatkan hasil bahwa tidak terdapat perbedaan yang signifikan $(\mathrm{p}=0,376)>0,05$ terhadap pengetahuan remaja mengenai PUP melalui pendidikan kesehatan dengan metode fasil.

Tabel 2: Perbedaan Pengetahuan Remaja mengenai Pendewasaan Usia Perkawinan melalui Pendidikan Kesehatan dengan Metode Simulation Game

\begin{tabular}{cccccc}
\hline \multirow{2}{*}{ Pengetahuan } & \multicolumn{3}{c}{ Metode Simulation Game } & \multirow{2}{*}{ Nilai p } \\
\cline { 2 - 4 } & Pre-test & \multicolumn{2}{c}{ Post-test } & \\
\cline { 2 - 4 } & $(\mathrm{n})$ & $(\%)$ & $(\mathrm{n})$ & $(\%)$ & \\
\hline Baik & 10 & 50 & 10 & 50 & 0,856 \\
Cukup & 6 & 30 & 8 & 40 & \\
Kurang & 4 & 20 & 2 & 10 & \\
\hline Total & 20 & 100 & 20 & 100 & \\
\hline
\end{tabular}

Berdasarkan tabel 2, didapatkan hasil bahwa tidak terdapat perbedaan yang signifikan $(\mathrm{p}=0,856)>0,05$ terhadap pengetahuan remaja mengenai PUP melalui pendidikan kesehatan dengan metode simulation game di SMP Negeri 1 Jatinangor.
Tabel 3: Perbandingan Pengetahuan Remaja mengenai Pendewasaan Usia Perkawinan melalui Pendidikan Kesehatan Metode Fasil dengan Simulation Game

\begin{tabular}{cccccccccc}
\hline & \multicolumn{3}{c}{ Metode Fasil } & \multicolumn{4}{c}{ Getode Simulation } \\
Pengetahu \\
an & \multicolumn{1}{c}{ Pre-test } & Post-test & \multicolumn{1}{c}{ Pre-test } & Post-test & Nila \\
& $\mathrm{n}$ & $\%$ & $\mathrm{n}$ & $\%$ & $\mathrm{n}$ & $\%$ & $\mathrm{n}$ & $\%$ & \\
\hline Baik & 3 & 15 & 7 & 35 & 10 & 50 & 10 & 50 & 0,404 \\
Cukup & 10 & 50 & 9 & 45 & 6 & 30 & 8 & 40 & \\
Kurang & 7 & 35 & 4 & 20 & 4 & 20 & 2 & 10 & \\
Total & 20 & 100 & 20 & 100 & 20 & 100 & 20 & 100 & \\
\hline
\end{tabular}

Berdasarkan tabel 3, didapatkan hasil bahwa tidak terdapat perbandingan yang signifikan $(\mathrm{p}=0,404)>0,05$ terhadap pengetahuan remaja mengenai PUP melalui pendidikan kesehatan metode fasil dengan simulation game.

Berdasarkan tabel 1 bahwa remaja yang memiliki pengetahuan baik sebelum diberikan pendidikan kesehatan sebanyak $15 \%$ dan setelah diberikan pendidikan kesehatan melalui metode fasil meningkat menjadi 35\%. Hasil analisa data menggunakan uji Wilcoxon didapatkan nilai $\mathrm{p}>0,05$, yaitu $\mathrm{p}=0,378$, yang dapat disimpulkan bahwa tidak terdapat perbedaan yang signifikan terhadap pengetahuan tentang PUP sebelum dan sesudah diberikan pendidikan kesehatan melalui metode fasil. Hal disebabkan oleh beberapa faktor diantanya adalah kondisi yang tidak kondusif karena pendidikan kesehatan ini dilakukan pada jam pulang sekolah. Sehingga responden menjadi kurang fokus dalam menerima penyampaian materi.

Hasil penelitian ini sejalan dengan penelitian yang dilakukan oleh Lana, menyatakan 
bahwa tidak ada pengaruh pemberian pendidikan kesehatan terhadap tingkat pengetahuan personal hygiene pada remaja putri Madrasah Tsanawiyah sebelum dan sesudah diberikan pendidikan kesehatan pada kelompok ceramah dan FGD dengan $\mathrm{p}>0,05$. Selain itu, terdapat perbandingan perubahan pengetahuan yang signifikan antara kelompok ceramah dan FGD setelah dilakukan pendidikan kesehatan dengan hasil kelompok ceramah lebih baik dari kelompok FGD. Hasil penelitian ini menunjukkan terdapat penurunan pengetahuan responden setelah dilakukan pendidikan kesehatan dengan FGD. Hal ini dapat disebabkan oleh beberapa faktor seperti lingkungan yang kurang kondusif dan pemateri yang tidak dapat mengontrol jalannya diskusi dengan baik. (Lana RA, 2015)

Hasil penelitian ini tidak sejalan dengan penelitian yang dilakukan oleh Aditya, menyatakan bahwa metode fasil (Focus Group Discussion - FGD) berpengaruh terhadap peningkatan pengetahuan tentang reproduksi remaja, dimana nilai $\mathrm{p}(0,000)$ $<0,005$. (Aditya NR, 2010)

Menurut Marianti, dari hasil penelitian yang telah dilakukan didapatkan hasil bahwa baik kelompok FGD ( $\mathrm{p}$ value $=0,000$ ) maupun kelompok CBIA (Community Based Interactive Approach) $(\mathrm{p}$ value $=0,002)$ memiliki perbedaan pengetahuan yang bermakna secara statistic antara sebelum dilakukan intervensi maupun sesudah dilakukan intervensi. Hasil dari Uji MannWhitney menunjukkan bahwa nilai significancy $0,012 \quad(\mathrm{p}<0,005), \quad$ sehingga dapat disimpulkan bahwa ada perbedaan bermakna antara kelompok FGD dengan CBIA. Rerata selisih skor pada kelompok FGD $(2,45)$ lebih besar dibandingkan CBIA (0,96). Sehingga, dapat disimpulkan bahwa metode FGD lebih baik dalam meningkatkan pengetahuan dibandingkan dengan metode CBIA walaupun keduanya sama-sama mengalami peningkatan pengetahuan. (Marianti; dkk, 2015)

Berdasarkan tabel 2 didapatkan hasil bahwa $50 \%$ memiliki pengetahuan baik sebelum dan sesudah diberikan pendidikan kesehatan melalui metode simulation game. Namun, hasil analisa menggunakan uji Wilcoxon tidak terdapat perbedaan (tidak signifikan) pengetahuan tentang PUP sebelum dan sesudah diberikan pendidikan kesehatan melalui metode simulation game, dimana nilai yang didapatkan p $(0,856)>0,05$. Kemungkinan ini dapat terjadi karena pada saat dilakukan pendidikan kesehatan dengan media permainan ular tangga, responden lebih terfokus pada permainan dan kurang memperhatikan saat materi disampaikan.

Hasil penelitian ini tidak sejalan dengan penelitian yang dilakukan oleh Nanda (2009) yang menyatakan bahwa metode simulation game berpengaruh terhadap peningkatan pengetahuan siswa kelas XI tentang kesehatan reproduksi remaja (KRR) di SMK Hidayah Semarang tahun 2009. (Aditya NR, 2010)

Menurut Siska, terdapat pengaruh pendidikan kesehatan dengan simulation game terhadap peningkatan pengetahuan, sikap, dan tindakan dalam melakukan perawatan kaki pada penderita diabetes mellitus pada usia pertengahan di Posyandu 
Lansia. $^{13}$ Perubahan pengetahuan yang diperoleh merupakan hasil dari pendidikan kesehatan. Konsep dari metode simulation game adalah belajar yang dikemas dalam bentuk permainan sehingga menciptakan suasana belajar yang menyenangkan, dinamis, penuh semangat, dan antusiasme. Selain itu, memungkinkan responden menangkap materi dengan efisien dan mengajak untuk berpartisipasi aktif dalam mengeksplor pengetahuan yang dimiliki. (Siska DP; dkk, 2014)

Berdasarkan tabel 3 diketahui bahwa hasil bahwa responden yang memiliki pengetahuan baik lebih banyak terdapat di kelompok simulation game yang berjumlah $50 \%$ dibandingkan dengan kelompok fasil yang berjumlah $35 \%$ setelah diberikan pendidikan kesehatan.

Hasil analisa data yang digunakan dengan menggunakan Uji Wilcoxon menunjukkan $\mathrm{p}$ value $=0,404$ sehingga disimpulkan bahwa tidak terdapat perbandingan yang signifikan ( $p>0,005)$ terhadap pengetahuan remaja mengenai PUP melalui pendidikan kesehatan dengan metode fasil dan simulation game. Hal tersebut terjadi baik metode fasil maupun simulation game memiliki kekurangan diantaranya pembicaraan menyimpang dari topik yang sudah diberikan dan responden terkadang lebih fokus terhadap permainan dibandingkan dengan materi yang disampaikan. (Aditya NR, 2010) Namun, pendidikan kesehatan yang dilakukan dengan metode fasil maupun simulation game dapat meningkatkan pengetahun responden mengenai PUP.
Penelitian ini sejalan dengan penelitian yang dilakukan oleh Nova, bahwa tidak ada perbedaan pengetahuan antara kelompok ceramah dan simulasi setelah diberikan pendidikan kesehatan. Rata-rata keterampilan antara kelompok ceramah dengan simulasi, yaitu 14,69<14,85. (Nova $K$, 2016) Karakteristik pengetahuan anak usia sekolah sudah bisa memahami dan menganalisa pengetahuan yang sudah diterima. Sehingga, rata-rata pengetahuan siswa sama sesudah diberikan pendidikan kesehatan. (Soekidjo N, 2012) Dapat disimpulkan bahwa pendidikan kesehatan dengan metode ceramah dan simulasi samasama meningkatkan rata-rata pengetahuan sesudah diberi pendidikan kesehatan. (Nova K, 2016)

\section{KESIMPULAN}

Metode pendidikan kesehatan dengan metode fasil dan simulation game dapat meningkatkan pengetahuan remaja mengenai PUP di SMP Negeri 1 Jatinangor. Namun, tidak terdapat perbedaan pengetahuan remaja mengenai PUP setelah diberikan pendidikan kesehatan dengan metode fasil maupun simulation game.

\section{UCAPAN TERIMA KASIH}

Ucapan terima kasih kepada BAPPEDA Kabupaten Sumedang dan Dinas Pendidikan Kabupaten Sumedang yang telah memberi izin untuk melakukan penelitian, SMP Negeri 1 Jatinangor sebagai lokasi penelitian, serta siswa-siswi kelas IX-5 di lokasi penelitian yang berpartisipasi dalam kegiatan penelitian ini. 
Puspa Sari, ${ }^{1}$ Ari Indra Susanti, ${ }^{2}$ Sri Astuti, ${ }^{3}$ Merry Wijaya ${ }^{4}$ Eka Noyan Nur Annisa ${ }^{5}$

Perbandingan Pengetahuan Remaja Mengenai Pendewasaan ...

\section{DAFTAR PUSTAKA}

Aditya NR. Perbedaan pengaruh antara metode focus group discussion (FGD) dengan metode simulation game (SIG) terhadap peningkatan pengetahuan siswa kelas XI tentang kesehatan reproduksi remaja di SMK Hidayah Semarang. Semarang: Universitas Negeri Semarang; 2010.

Desiyanti IW. Faktor-faktor yang berhubungan terhadap pernikahan dini pada pasangan usia subur di Kecamatan Mapanget Kota Manado. JIKMU. 2015 2 April;5(2):274-75.

Fadlyana E, Larasaty S. Pernikahan usia dini dan permasalahannya. Jurnal Sari Pediatri. 2009;11(2):136-40.

Hodgkinson S, Colantuoni E, Roberts D, Berg-Cross L, Belcher H. Depressive symptoms and birth outcomes among pregnant teenagers. Journal Pediatr Adolesc Gynecol. 2010:16-22.

Kemenkes. InfoDatin : Pusat data dan informasi kementerian kesehatan RI. In: Indonesia KKR, editor. Jakarta; 2012.

Lana, RA. Pengaruh pendidikan kesehatan terhadap tingkat pengetahuan personal hygiene pada remaja putri. Yogyakarta: Fakultas Kedokteran dan Ilmu Kesehatan Universitas Muhammadiyah Yogyakarta; 2015

Marianti; dkk. Perbandingan metode CBIA dan FGD dalam peningkatan pengetahuan dan ketepatan caregiver dalam upaya swamedikasi demam pada anak. Purwokerto: Fakultas Farmasi Universitas

Muhammadiyah Purwokerto; 2015.

Morris JL, Rushwan H. Adolescent sexual and reproductive health : The global challengs. International Journal of Gynecology and Obstetrics. 2015 October 2015;131:S40-S2.

Nova, K. Efektivitas pendidikan kesehatan terhadap perubahan pengetahuan dan keterampilan P3K pada siswa PMR di SMA Negeri 3 Sukoharjo. Surakarta: Fakultas Ilmu Kesehatan Universitas Muhammadiyah Surakarta; 2016

Pitojo AJ LS, Kiswanto E, Hasmi E. Ayo menjadi remaja berkarakter : religius, sehat, cerdas, produktif. In: BKKBN, editor. Jakarta: Perpustakaan Nasional RI; 2013.

Riset Kesehatan Dasar (RISKESDAS) 2010. Jakarta: Badan Penelitian dan Pengembangan Kesehatan Kementerian Kesehatan RI; 2010.

Siska, DP; dkk. Pendidikan kesehatan metode simulation game meningkatkan perilaku penderita diabetes mellitus dalam melakukan perawatan kaki di Posyandu Lansia Simoangin-Angin Sidoarjo. Surabaya: Universitas Airlangga; 2014 
Puspa Sari, ${ }^{1}$ Ari Indra Susanti, ${ }^{2}$ Sri Astuti, ${ }^{3}$ Merry Wijaya ${ }^{4}$ Eka Noyan Nur Annisa ${ }^{5}$

Perbandingan Pengetahuan Remaja Mengenai Pendewasaan ...

Soekidjo N. Promosi kesehatan dan perilaku kesehatan. Jakarta: PT Rineka Cipta; 2012.

Stang EM. Faktor yang berhubungan dengan pernikahan dini di Kelurahan Pangli Kecamatan Sesean Kabupaten Toraja Utara. Jurnal MKMI. 2011 April, 2011;7:105-10. 